\title{
Characterization of the Sexual Self- and Cross-Compatibility in Genotypes of Cacao
}

\author{
Samuel Martins de Jesus Branco', Daniela Viana da Silva1, \\ Uilson Vanderlei Lopes ${ }^{2}$, Ronan Xavier Corrêa ${ }^{1}$ \\ ${ }^{1}$ Universidade Estadual de Santa Cruz, Ilhéus, Brazil \\ ${ }^{2}$ Centro de Pesquisas do Cacau (CEPEC/CEPLAC), Ilheus, Brazil \\ Email: samuelbranco2005@hotmail.com,dani_dvs@hotmail.com, uilson@cepec.gov.br, ronanxc@uesc.br
}

How to cite this paper: de Jesus Branco, S.M., da Silva, D.V., Lopes, U.V. and Corrêa, R.X. (2018) Characterization of the Sexual Self- and Cross-Compatibility in Genotypes of Cacao. American Journal of Plant Sciences, 9, 1794-1806.

https://doi.org/10.4236/ajps.2018.99131

Received: March 29, 2018

Accepted: August 6, 2018

Published: August 9, 2018

Copyright $\odot 2018$ by authors and Scientific Research Publishing Inc. This work is licensed under the Creative Commons Attribution International License (CC BY 4.0).

http://creativecommons.org/licenses/by/4.0/

\begin{abstract}
Cacao is a tree crop of high economic importance and the subject of several studies aiming the genetic improvement of the species with the incorporation of characteristics that are agronomically important to create superior genotypes. In this context, this study aimed to characterize 22 genotypes of cacao for sexual compatibility, which is a trait that is strongly associated with yield. Additionally, we identify genotypes incompatible with clone TSH-1188 through controlled intercrosses, due to the great importance of this clone in cocoa breeding. Fifteen genotypes were characterized as self-incompatible and other seven as self-compatible, considering the retention index (20\%) of self-pollinated flowers. Nine genotypes were characterized for the first time: CCN-16, COCA-3310, COCA-3370/5, EB-1017, IMC-119, IMC-97, LCTEEN-37A, NA-45, and UF-612. Cacao genotypes showed flower retention index ranging from $0.0 \%$ to $55.1 \%$ after 15 days of self-pollinations. The number of retained flowers varied after self-pollination of cacao genotypes at 1, 5 and 15 days after pollination. CCN-51, Catongo, $\mathrm{CCN}-10$ and $\mathrm{P}-4 \mathrm{~B}$, were the genotypes with minor losses of flowers after 15 days of pollination, while IMC-119 and TSH-516 had 100\% of loss of flowers between 1 and 5 days after pollination. Moreover, the flower retention index 15 days after cross-pollination with TSH-1188 ranged from $0.0 \%$ to $87.5 \%$ among the tested genotypes. The results of cross-pollinations identified two genotypes that are incompatibles, EB-1017 and IMC-119. This result is important for future allelic studies of incompatibility in cacao, because it might indicate that these genotypes share the same self-incompatibility allele(s). We conclude, therefore, that this study enable the characterization of this working collection of cocoa germplasm for sexual compatibility and this information is important for subsequent crosses between cacao genotypes.
\end{abstract}




\section{Keywords}

Breeding System, Pollination, Retention Index, Cocoa Germplasm, Theobroma cacao

\section{Introduction}

Theobroma cacao L. (cacao) is a tree of the Malvaceae family that has great economic importance because of its use in the manufacturing of cosmetics, juices, pulps, and especially chocolate [1]. The cacao flowers, grouped in flower cushions, appear on the trunk and on the branches. They are hermaphrodite and composed of five petals, five sepals, five staminodes, five stamens and a pistil, and the natural pollination occurs mainly by insects of the genus Forcipomyia Meigen, 1818 [2] [3] [4]. The tree produces approximately 125.000 flowers per year; however, fertilization rates are low and only about $2 \%$ will set fruits [5] [6] [7].

Sexual compatibility is a feature of utmost importance for the genetic improvement of cacao, because it is directly associated with yield [8]. Self-compatible plants produce more fruits than self-incompatibles, and, therefore, it should be considered as relevant to plan crosses aiming at increased production, as well as for selection of possible clones classified as agronomically satisfactory [9] [10].

The mechanisms of sexual incompatibility exist in nature and favor the genetic variability of the species, because they avoid the self-fertilization that would cause increased homozygosis [11]. These mechanisms act on rejection of pollen, non-germination of pollen, disruption of pollen tube growth and in the embryo development [2] [11] [12].

Self-incompatibility is controlled by different alleles and two processes can be reported, gametophytic and sporophytic influence [7] [10]. The gametophytic self-incompatibility is determined by the male gamete with haploid pollen, while the female spore with a diploid maternal genotype determines the sporophytic self-incompatibility [2] [11] [12].

Self-incompatibility in cacao possibly occurs in the ovary with the activation of the recognition $S$ gene, resulting in the reaction of rejection between the ovule and the pollen tube that subsequently will cause the excision of flowers, usually after 72 hours of self-pollination [13] [14]. Self-incompatibility prevents syngamy (fertilization) by biochemical processes of recognition and rejection; while in self-compatible plants after of the pollination ( 24 to 48 hours after) fusion occurs between the plasma membrane of a sperm cell and the egg cell, and syngamy occurs when the other sperm cell fuses with the polar nuclei [13] [15] [16] [17].

Cope [13] analyzed the results of self-pollination of self-compatible clones and proposed the hypothesis of degrees of self-compatibility, and this is explained by the introduction of two pairs of independent genes, A and B, complementary and modifiers of the $S$ gene of incompatibility. 
In cacao, it is possible to find self-compatible and self-incompatible varieties, and this difference is the target of different studies [9] [13] [18]. In this context, the objectives of our study were to characterize the self-compatibility status in different genotypes of cacao, and the inter-compatibility status with clone TSH-1188 through artificial pollination crosses.

\section{Material and Methods}

This study used 22 genotypes of $T$. cacao widely found in farms or used in breeding programs: eleven wild genotypes COCA-3310, COCA-3370/5, EB-1017, IMC-67, IMC-97, IMC-119, LCTEEN-37A, NA-45, PA-150, PA-303, Sca-19 and eleven tamed genotypes Catongo, CCN-10, CCN-16, CCN-51, ICS-40, P-4B, TSH-516, TSH-565, TSH-1188, UF-612, SIC-628. Each genotype possessed five plants (clones) arranged in line on a working collection of cocoa germplasm. All trees are located at the Mars Center for Cocoa Science (MCCS), Barro Preto, Bahia, Brazil, $14^{\circ} 42^{\prime} 45.021171^{\prime \prime S}$ and $39^{\circ} 22^{\prime} 13.008369^{\prime \prime W}$. Most of these genotypes are international clones, available in different countries.

Artificial self- and cross-pollinations were performed between 2011 and 2013. At least 40 flowers of each genotype were pollinated, and only healthy flowers were used in the pollination procedure. One day before pollination, floral buttons (those with the appearance that they would open the next day) were protected using polyethylene tubes fixed on trunk with a rubber band, thus avoiding unwanted pollination caused by wind or insects; only the open-protected flowers were used as male and female parents.

Pollination occurred in the day after the protection of flowers; therefore, on that day the flowers were newly open. In the flowers selected as male parents, the petals were removed, exposing the stamens with their pollen. In the flowers selected as female parents, all staminodes around the pistil were removed. After that, anthers of flowers selected as male parents were rubbed on the stigma of the flowers chosen as female parents [19] [20] [21]. After the pollination, flowers were identified with date of the pollination and name of female and male parents used, and protected again with polyethylene tube fixed onto the trunk with a rubber band.

Self-compatibility was determined in 22 genotypes. Inter-compatibility was determined by cross-pollination using TSH-1188 genotype as male parent crossed with 16 genotypes: Catongo, CCN-10, CCN-51, COCA-3370/5, EB-1017, EB-1230, IMC-97, IMC-119, LCTEEN-37A, NA-45, P-4B, PA-150, Sca-19, SIC-628, TSH-565, UF-612. The genotypes CCN-16, COCA-3310, ICS-40, IMC-67, PA-303 and TSH-516 did not possess enough flowers for this evaluation. TSH-1188 genotype was used as male parent, in this study, due of its high importance in the cacao genetic improvement in Brazil [22] [23] [24]. This genotype came from a successful breeding program in Trinidad and Tobago, and it is an important source of resistance to disease, yield potential and quality [25].

Retained flowers in self- and inter-compatibility were evaluated at 1, 5, and 15 
days after pollination for all genotypes. This study used the retention index of at least $20 \%, 15$ days after pollination, to characterize the genotypes as self- and inter-compatible with TSH-1188, values below $20 \%$ were characterized as self- and inter-incompatible with TSH-1188 [21]. Retention index was calculated as the number of pollinated flowers retained on trees after pollination, multiplied by 100 , and divided by the total number of pollinated flowers. The final characterization of the genotypes based on retention index 15 days after pollination.

In the statistical analysis, the software SISVAR 5.4 was used [26], which includes the analysis of variance (ANOVA) between genotypes cross-compatible and cross-incompatible with TSH-1188, and descriptive statistics: average retention index, amplitude, variance and standard deviation.

\section{Results and Discussion}

Cacao genotypes showed flower retention index ranged from $0.0 \%$ to $55.1 \%$ after 15 days of self-pollinations. Eight genotypes showed a flower retention index of $0.0 \%$, seven genotypes between $1.4 \%$ and $7.5 \%$, and seven genotypes between $28.0 \%$ and $55.1 \%$, especially CCN-51 (55.1\%), Catongo (54.8\%), CCN-10 (50\%) and $\mathrm{P}-4 \mathrm{~B}(50 \%)$.

The flower retention index 15 days after cross-pollination with TSH-1188 ranged from $0.0 \%$ to $87.5 \%$ among the tested genotypes. After the controlled cross-pollination, only two genotypes showed flower retention index below $20 \%$; EB-1017 (0.0\%) and IMC-119 (7.3\%). The other 14 genotypes had flower retention index between $30.0 \%$ and $87.5 \%$ (Table 1 ).

The basic method that researchers use to characterize the cacao genotypes for their compatibility is to count the number of flowers that remain attached to the trees after an interval of time of pollination, usually 15 days after pollination. Some authors consider the genotypes as compatible when they show levels of retention of $2 \%$ of the flowers pollinated [27], above $5 \%$ of the flowers pollinated [14] [28] [29] [30], at least $10 \%$ of the flowers pollinated [31]. Leal [32] considered a plant as compatible when the flower retention was above $14 \%$ of the flowers pollinated, Cadavid-Vélez [21] considers compatible plants with more than $20 \%$ of the flower retention, and Castillo [33] only above $40 \%$ of the flowers pollinated.

The minimum retention index of $20 \%$ [21] was satisfactory to estimate the compatibility of all 22 genotypes used in this study, because it reliably allowed the classification of self-compatible and self-incompatible genotypes. Fifteen genotypes were classified as self-incompatible and seven ones as self-compatible, considering the minimum flower retention index of $20 \%$. Fourteen genotypes were classified as cross-compatible with TSH-1188, and two ones were classified as cross-incompatible.

Other authors characterized the reaction of compatibility of part of the genotypes used in this study and found results similar to those of our study, especially 
Table 1. Flower retention index (RI) 15 days after hand pollination of different cacao genotypes. Self-pollination in 22 genotypes and the final status of self-compatibility (Sc, if $\mathrm{RI} \geq 20 \%$ ) and self-incompatibility ( $\mathrm{Si}$, if $\mathrm{RI}<20 \%$ ). Cross-pollination of 16 genotypes with TSH-1188 and the final status of compatibility (C, if $\mathrm{RI} \geq 20 \%)$ and incompatibility (I, if RI <20\%).

\begin{tabular}{|c|c|c|c|c|}
\hline \multirow{2}{*}{ Cacao genotype } & \multicolumn{2}{|c|}{ Self-pollination } & \multicolumn{2}{|c|}{ Cross-pollination } \\
\hline & RI & Status & RI & Status \\
\hline Catongo & 54.8 & $\mathrm{Sc}$ & 38.1 & $\mathrm{C}$ \\
\hline $\mathrm{CCN}-10$ & 50.0 & $\mathrm{Sc}$ & 58.5 & $\mathrm{C}$ \\
\hline $\mathrm{CCN}-16$ & 1.4 & $\mathrm{Si}$ & . & . \\
\hline CCN-51 & 55.1 & Sc & 37.8 & $\mathrm{C}$ \\
\hline COCA-3310 & 28.0 & $\mathrm{Sc}$ & . & . \\
\hline COCA-3370/5 & 4.4 & $\mathrm{Si}$ & 60.0 & $\mathrm{C}$ \\
\hline EB-1017 & 6.4 & $\mathrm{Si}$ & 0.0 & I \\
\hline EB 1230 & . & . & 57.5 & $\mathrm{C}$ \\
\hline ICS-40 & 0.0 & $\mathrm{Si}$ & . & . \\
\hline IMC-119 & 0.0 & $\mathrm{Si}$ & 7.3 & I \\
\hline IMC-67 & 2.5 & $\mathrm{Si}$ & . & . \\
\hline IMC-97 & 4.4 & $\mathrm{Si}$ & 57.5 & $\mathrm{C}$ \\
\hline LCTEEN-37A & 5.0 & $\mathrm{Si}$ & 70.0 & $\mathrm{C}$ \\
\hline NA-45 & 7.5 & $\mathrm{Si}$ & 77.5 & $\mathrm{C}$ \\
\hline P-4B & 50.0 & $\mathrm{Sc}$ & 75.0 & $\mathrm{C}$ \\
\hline PA-150 & 46.3 & $\mathrm{Sc}$ & 70.7 & $\mathrm{C}$ \\
\hline PA-303 & 0.0 & $\mathrm{Si}$ & . & . \\
\hline Sca-19 & 0.0 & $\mathrm{Si}$ & 30.0 & $\mathrm{C}$ \\
\hline SIC-628 & 28.6 & $\mathrm{Sc}$ & 55.0 & $\mathrm{C}$ \\
\hline TSH-1188 & 0.0 & $\mathrm{Si}$ & 0.0 & I \\
\hline TSH-516 & 0.0 & $\mathrm{Si}$ & . & . \\
\hline TSH-565 & 0.0 & $\mathrm{Si}$ & 87.5 & $\mathrm{C}$ \\
\hline UF-612 & 0.0 & $\mathrm{Si}$ & 75.0 & $\mathrm{C}$ \\
\hline
\end{tabular}

(.) Data not disponible.

for the genotypes TSH-1188, TSH-516, TSH-565, CCN-10, CCN-51 and CCN-16 [34]. The importance of testing these genotypes is justified by their frequent use in breeding studies and in commercial plantations. The CCN-51 and Catongo genotypes are widely used in studies that seek the genetic improvement of cacao associated with witches' broom, and are widespread in cacao plantations [35]. Other genotypes such as CCN-16, COCA-3310, Coca-3370/5, EB-1017, IMC-119, IMC-97, LCTEEN-37A, NA-45, and UF-612 were characterized here for the first time. These genotypes were chosen for this study due to their characteristics of agronomic interest and utility for genetic improvement of cacao studies [35] 


\section{[36] [37] [38].}

TSH-1188 was classified as self-incompatible. It is a genotype resistant to various diseases such as witches' broom and Ceratocystis wilt; however, its level of production is not higher due to its self-incompatibility [39]. This genotype was used as a male parent in pollinations and showed high levels of cross-compatibility. It was compatible with 14 genotypes: Catongo, CCN-10, CCN-51, COCA-3370/5, EB-1230, IMC-97, LCTEEN-37A, NA-45, P-4B, PA-150, Sca-19, SIC-628, TSH-565, UF-612. However, TSH-1188 was cross-incompatible with EB-1017 and IMC-119.

Retention index for flowers of TSH-565 after cross-pollination with TSH-1188 was $87.5 \%$, which might indicate greater affinity between these genotypes. Our results show that the use of TSH-1188 as one of the genotypes grown with other genotypes in a commercial plantation could potentially contribute to increased production as mentioned in Cadavid-Vélez [21]. Although TSH-565 and TSH-1188 are self-incompatible, when inter-crossed between each other they have a high flower retention index. This result is relevant due to characteristic of witches' broom resistance that both genotypes present, because progenies originating from this crossing may contain self-compatible genotypes and resistant to witches' broom.

The number of retained flowers varied after self-pollination of 22 cacao genotypes at 1,5 and 15 days after pollination. CCN-51, Catongo, CCN-10 and P-4B, were the genotypes with minor losses of flowers after 15 days of pollination, while IMC-119 and TSH-516 had 100\% of loss of flowers between 1 and 5 days after pollination. Highlights that the IMC-119 had $90 \%$ of loss of flowers after 1 day of pollination (Figure 1(a)). Analysis of the flower retention index of all genotypes showed a loss of $25.1 \%$ in the first 24 hours after pollination, $53.7 \%$ after 5 days and $86.7 \%$ after 15 days of self-pollination. The number of self-incompatible genotypes of this study influences this result (Figure 1(b)). When analyzed self-compatible genotypes (Catongo and CCN-51) and self-incompatible genotypes (EB-1017 and IMC-119), separately, it is possible to verify a higher flower retention index in the three periods of evaluation (1,5 and 15 days) among the self-compatible genotypes (Figure 1(c)).

The number of retained flowers after cross-pollination of 16 cacao genotypes at 1, 5 and 15 days after pollination varied (Figure 2(a)). Analysis of the flower retention index of all genotypes showed a loss of $9.2 \%$ in the first 24 hours after pollination, $42.3 \%$ after 5 days and $47.3 \%$ after 15 days of cross-pollination. The low number of incompatible genotypes when crossed with TSH-1188 influenced this result (Figure 2(b)).

Evaluation of flower retention at 1,5 and 15 days after self-pollination indicates that the biochemical reactions of incompatibility result in excision of flowers in plants. A similar evaluation after cross-pollination with TSH-1188 showed a difference in the number of the flower excisions after 1, 5 and 15 days. The smaller excision presented at crossings with TSH-1188 can be explained by the presence of only two genotypes incompatible with TSH-1188. 

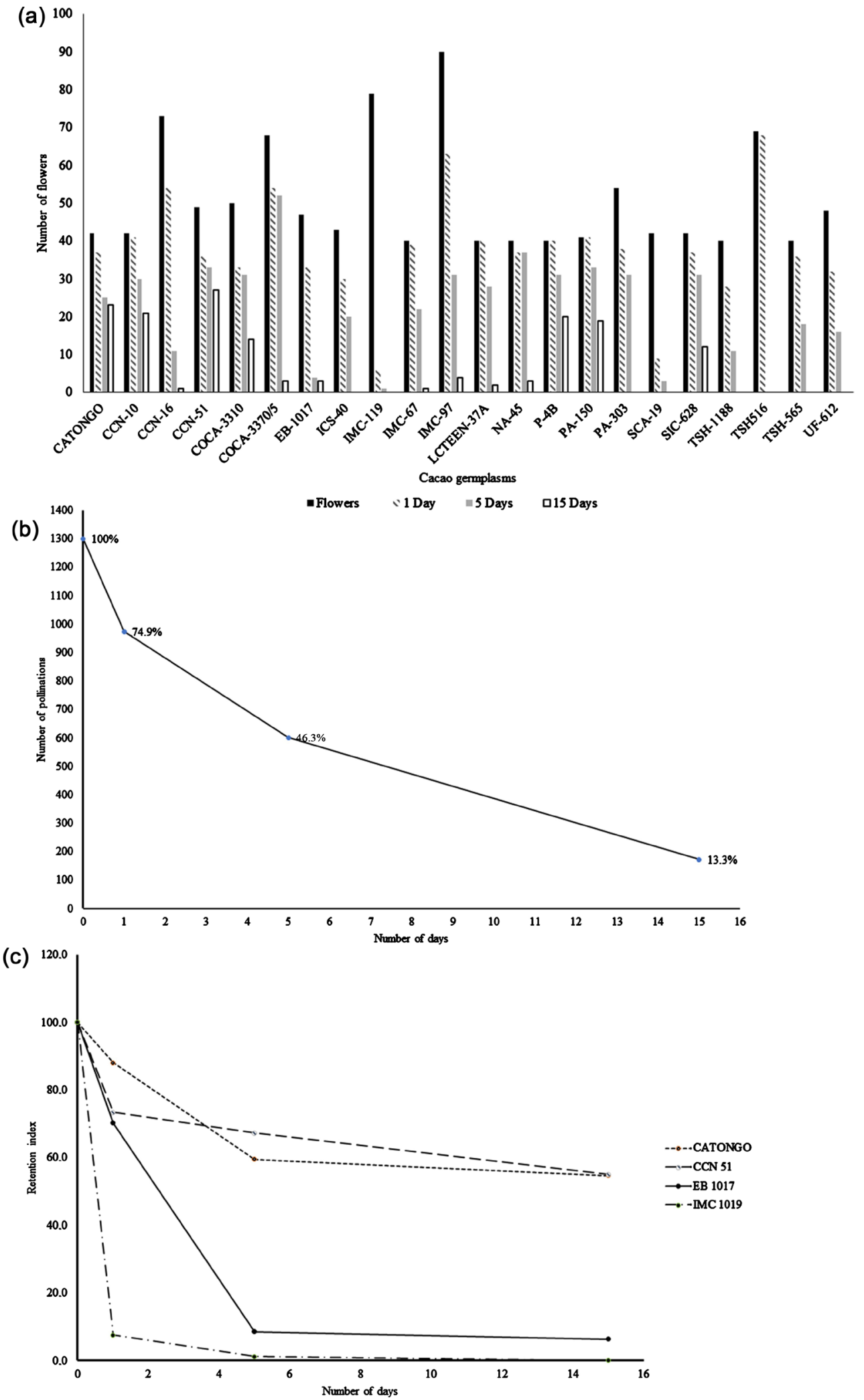

Figure 1. Self-pollination in Theobroma cacao genotypes. (a) Number of retained flowers after self-pollination of 22 cacao genotypes at 1,5 and 15 days after pollination. (b) Total number of pollinations made in 22 Theobroma cacao genotypes and the decrease in the retention index of selfed flowers over the days after pollination. (c) Retention index in two self-compatible genotypes (Catongo and CCN-51) and two self-incompatible genotypes (EB-1017 and IMC-119). 
(a)

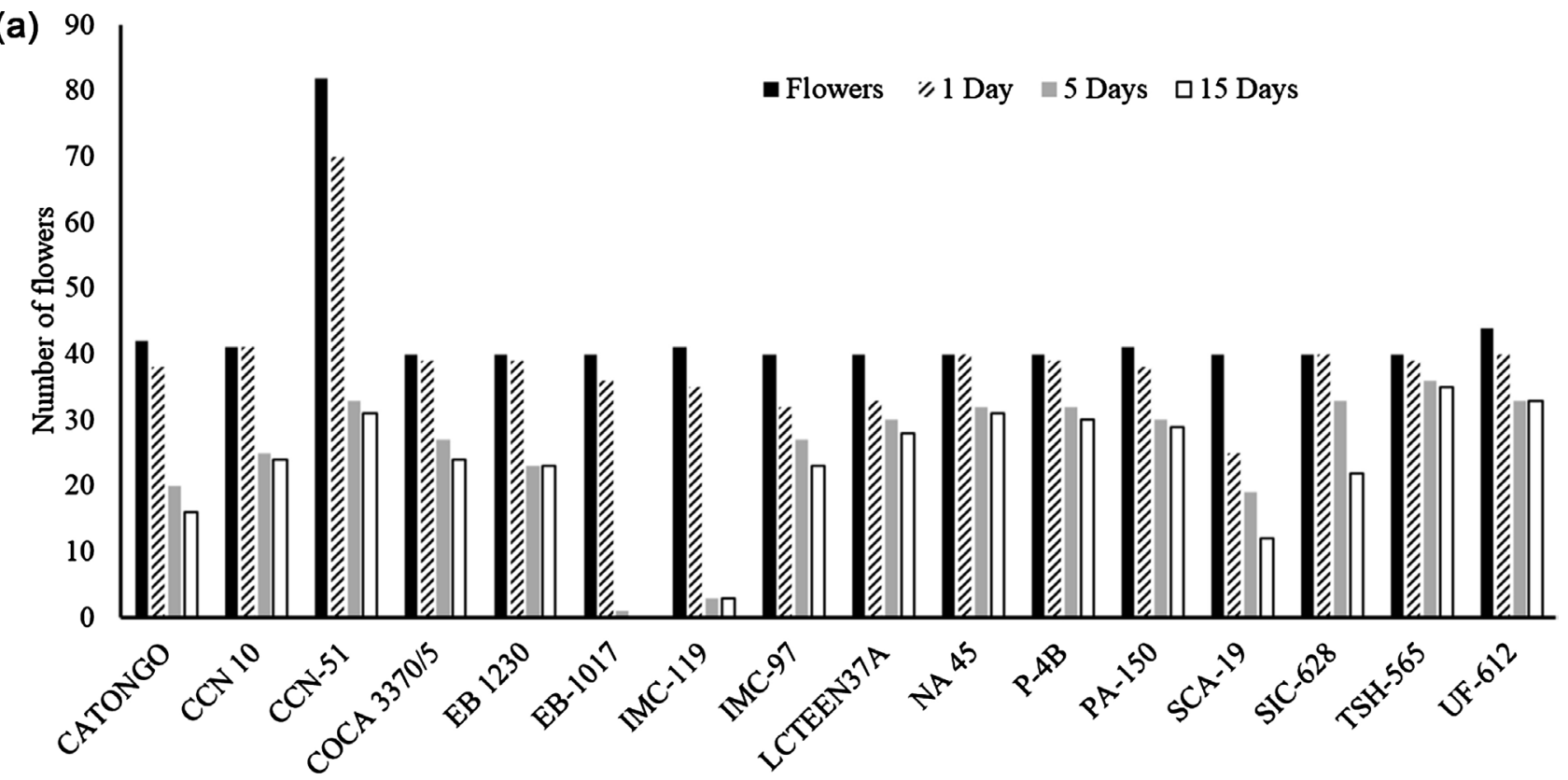

Cacao germplasms

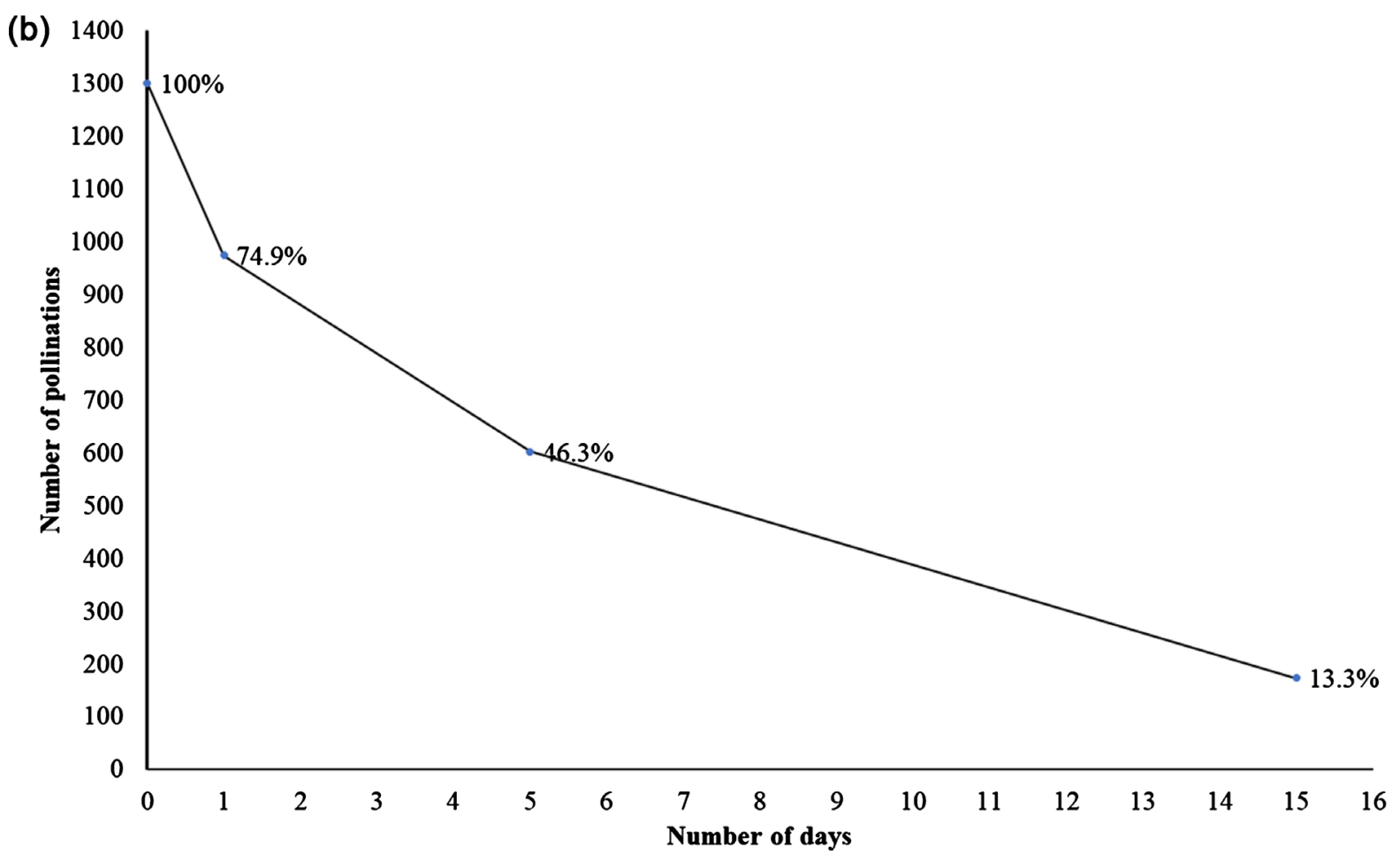

Figure 2. Cross-pollination in Theobroma cacao germplasms. (a) Number of retained flowers of 16 cacao genotypes in 1, 5 and 15 days after the cross-pollination with TSH-1188. (b) Total number of pollinations made in 16 genotypes of Theobroma cacao and the decrease in the retention index of the cross-pollinated flowers with TSH-1188 over the days after pollination.

Genotypes EB-1017 and IMC-119 were cross-pollinated with TSH-1188 at the same periods the other genotypes were cross-pollinated with TSH-1188. Here we show four different periods of pollination with the number of pollinated flowers and the number of retained flowers in each period (Figure 3). The incompatibility 
of these genotypes (EB-1017 and IMC-119) with TSH-1188 occurred in the four different periods of pollination. This result is important for future allelic studies of incompatibility in cacao, because might indicate that these genotypes share the same SI allele(s).

The flower retention index of all genotypes 15 days after the self-pollination was used in the statistical analysis. In this study, the average retention index was $15.6 \%$, with amplitude of $0.0 \%$ to $55.1 \%$, variance of $434.6 \%$ and standard deviation of $20.8 \%$. When the 16 genotypes were cross-pollinated with TSH-1188 average flower retention index was $53.6 \%$, with amplitude of $0.0 \%$ to $87.5 \%$, variance of $584.9 \%$, and standard deviation of $24.2 \%$. ANOVA analysis showed statistically significant differences between genotypes cross-compatible and cross-incompatible with TSH-1188 (Table 2). The explanation for this increase of average retention index in cross-pollinated genotypes with THS-1188 is associated with number of cross-compatible genotypes $(81.25 \%)$, while in the self-pollination the number of self-compatibles genotypes was $31.08 \%$.

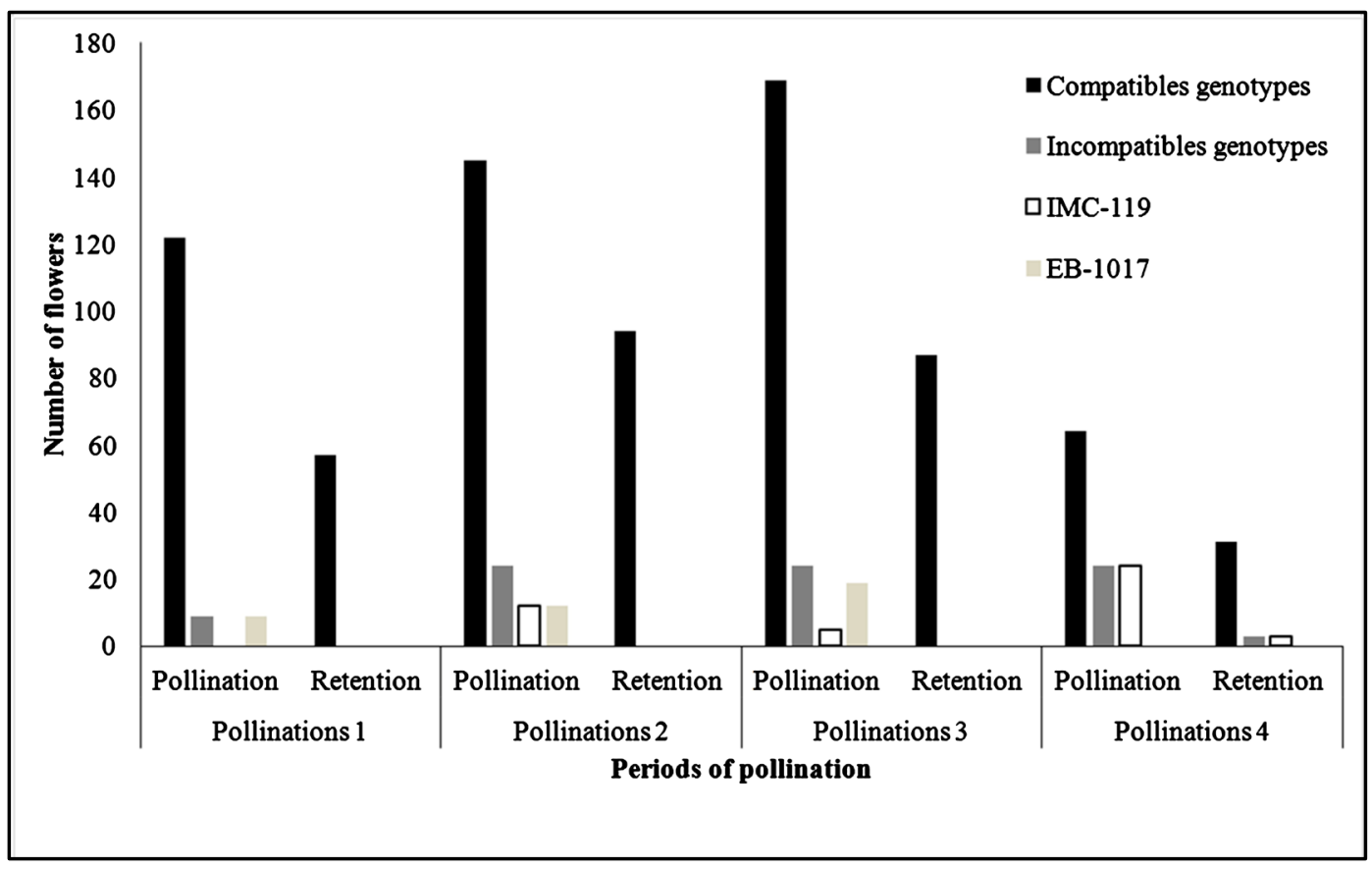

Figure 3. Evaluation of retained flowers of genotypes with cross-pollination with TSH-1188 in different periods of pollination.

Table 2. Analysis of variance for flower retention index of the group of genotype classified cross-compatible and cross-incompatible with genotype TSH-1188 $(P<0.05)$.

\begin{tabular}{ccccc}
\hline Variable factor & Degrees of freedom & SQ & QM & $\begin{array}{c}\text { Fc } \\
\text { Pr }>\text { Fc }\end{array}$ \\
\hline Index & 1 & 4945.151250 & 4945.151250 & 92.885 \\
Error & 6 & 319.437500 & 53.239583 & 0.0001 \\
Total & 7 & 5264.588750 & & \\
\hline
\end{tabular}

$\mathrm{CV}(\%)=26.07$. 
Statistical analyses showed that retention index was higher for cross-pollination than for self-pollination, confirming the important role of the insertion of different genotypes in the plantation in farms that aimed at production. By the ANOVA analysis, we showed significant difference between genotypes compatible and incompatible with TSH-1188.

\section{Conclusion}

Our study extends the knowledge about sexual self compatibility of cocoa clones, and their inter compatibility with TSH-1188. This extended classification allows breeders to better plan their crosses with the aim of developing improved self-compatible varieties, as well as for farmers to plan their fields in order to maximize the success in pollination.

\section{Acknowledgements}

This study was funded by the Mars Center for Cocoa Science-MCCS. RXC was granted of fellowships from Conselho Nacional de Desenvolvimento Científico e Tecnológico-CNPq (Grant n. 481074/2013-9 and 307915/2012-3), and DVS and SMJB was granted of Doctorate fellowships from Coordenação de Aperfeiçoamento de Pessoal de Nível Superior-CAPES.

\section{Conflict of Interest}

The authors declare that they have no conflict of interest.

\section{Author's Contribution Statement}

SMJB and DVS conducted the study and wrote the manuscript. UVL and RXC conceived and guided the research. All authors read and approved the manuscript.

\section{Key Message}

The main achievements of our work were extend the knowledge about sexual self compatibility of cacao clones and characterize some genotypes for the first time.

\section{References}

[1] Alverson, W.S., Whitlock, B.A., Nyffeler, R., Bayer, C. and Baum, D.A. (1999) Phylogeny of the Core Malvales: Evidence from ndhF Sequence Data. American Journal of Botany, 86, 1474-1486. https://doi.org/10.2307/2656928

[2] De Nettancourt, D. (2000) Incompatibility and Incongruity in Wild and Cultivated Plants. Springer, Berlin.

[3] Souza, C.A.S. and Dias, L.A.S. (2001) Melhoramento Ambiental e Sócio-Economia. In: Dias, L.A.S., Ed., Melhoramento Genético do Cacaueiro, FUNAPE, Viçosa, 1-47.

[4] Guillermo-Ferreira, R. and Vilela, D.S. (2013) New Records of Forcipomyia (Pterobosca) incubans (Diptera: Ceratopogonidae) Parasitizing Wings of Odonata in Brazil. Biota Neotropica, 13, 360-362. 
https://doi.org/10.1590/S1676-06032013000100037

[5] Alvim, P.T. (1984) Flowering of Cocoa. Cocoa Growers' Bulletin, 25, 23-31.

[6] Lachenaud, P. and Mossu, G. (1985) Etude comparative de l'influence de deux modes de conduite sur lês facteurs du redement d'une cacaoyère. Cafe Cacao Thé, 29, 21-30.

[7] Bartley, B.G. (2005) The Genetic Diversity of Cacao and Its Utilization. CABI Publishing, Massachusetts. https://doi.org/10.1079/9780851996196.0000

[8] Pires, J.L., Rosa, E.S. and Macedo, M.M. (2012) Avaliação de clones de cacaueiro na Bahia. Agrotropica, 24, 79-84. https://doi.org/10.21757/0103-3816.2012v24n2p79-84

[9] Bartley, B.G.D. and Yamada, M.M. (1982) Efeito da incompatibilidade sobre a produtividade. Informe Técnico, CEPEC, Ilhéus.

[10] Dias, L.A.S. (2001) Melhoramento genético do cacaueiro. Editora Folha de Viçosa, Viçosa.

[11] De Nettancourt, D. (1997) Incompatibility in angiosperms. Sexual Plant Reproduction, 10, 185-199. https://doi.org/10.1007/s004970050087

[12] Heslop-Harrison, J. (1983) Self-Incompatibility: Phenomenology and Physiology. Proceedings of the Royal Society of London B, 218, 371-395. https://doi.org/10.1098/rspb.1983.0046

[13] Cope, F.W. (1962) The Mechanism of Pollen Incompatibility in Theobroma cacao L. Heredity, 17, 157-182. https://doi.org/10.1038/hdy.1962.14

[14] Bartley, B.G.D. and Cope, F.W. (1973) Practical Aspects of Self-Incompatibility in Theobroma cacao L. In: Moav, R., Ed., Agricultural Genetics-Selected Topics, Wiley, New York, 109-134.

[15] Cheesman, E.E. (1927) Fertilization and Embryogeny in Theobroma cacao L. Annals of Botany, 41, 107-126. https://doi.org/10.1093/oxfordjournals.aob.a090058

[16] Cope, F.W. (1958) Incompatibility in Theobroma cacao. Nature, 181, 279. https://doi.org/10.1038/181279a0

[17] Bouharmont, J. (1960) Recherches cytologiques sur la fructification et l'incompatibilité chez Theobroma cacao L. L'institut National pour P Etude Agronomique du Congo, $89,113$.

[18] Yamada, M.M., Bartley, B.G.D., Castro, G.C.T. and Melo, G.R.P. (1982) Herança do fator incompatibilidade em Theobroma cacao L. I. Relações fenotípicas na família PA (Parinari). Revista Theobroma, 12, 163-167.

[19] Carletto, G.M. (1946) A polinização controlada na flor do cacaueiro. Boletim Técnico do Instituto de Cacau, 6, 5-30.

[20] Hardy, F. (1960) Fungus Diseases of Cacao and Their Control. In: Hardy, F., Ed., Cacao Manual, Inter-American Institute of Agricultural Sciences, Turrialba, 242-245.

[21] Cadavid-Velez, S. (2006) Características de compatibilidad sexual de algunos clones de cacao y su aplicación en siembras comerciales. Compañía Nacional de Chocolates, Colombia.

[22] Bahia, R.C., Corrêa, R.X., Santos, R.C., Machado, R.C.B., Luz, E.D.N., Araújo, I.S. and Ahnert, D. (2013) Inheritance of the Number of Ovules per Ovary and Selection of Cacao Genotypes. American Journal of Plant Sciences, 4, 1387-1392. https://doi.org/10.4236/ajps.2013.47169

[23] Barreto, M.A., Santos, J.C.S., Corrêa, R.X., Luz. E.D.M.N., Marelli, J. and Souza, A.P. (2015) Detection of Genetic Resistance to Cocoa Black Pod Disease Caused by 
Three Phytophthora Species. Euphytica, 206, 677-687. https://doi.org/10.1007/s10681-015-1490-4

[24] Royaert, S., Jansen, J., Silva, D.V., Branco, S.M.J., Livingstone III, D.S., Mustiga, G., Marelli, J.P., Araújo, I.S., Corrêa, R.X. and Motamayor, J.C. (2016) Identification of Candidate Genes Involved in Witches' Broom Disease Resistance in a Segregating Mapping Population of Theobroma cacao L. in Brazil. BMC Genomics, 17, 1-16. https://doi.org/10.1186/s12864-016-2415-x

[25] Maharaj, K.P., Bekele, F.L., Ramnath, D., Bidaisee, G.G., Bekele, I., Persad, C., Jennings, K. and Sankar, R. (2011) Trinidad Selected Hybrids: An Investigation of the Phenotypic and Agro-Economic Traits of 20 Selected Cacao Cultivars. Tropical Agriculture, 88, 175-185.

[26] Ferreira, D.F. (1998) SISVAR—Sistema de análise de variância para dados balanceados. UFLA, Lavras.

[27] López, B.O. (1982) Revisión de Literatura sobre la incompatibilidad en Cacao. CATIE, Turrialba.

[28] León, J. (2000) Botánica de los Cultivos Tropicales. IICA, San José.

[29] Lopes, U.V. and Carletto, G.A. (1995) Tamanho de amostra para estudos de caracterização de germoplasma de cacaueiro quanto à incompatibilidade. Informe de Pesquisas 1987/1990, CEPLAC/CEPEC, Ilhéus.

[30] Terreros, J.R., Chavarro, G. and Ocampo, F.R. (1982) Determinacion de los genotipos de incompatibilidad o compatibilidad en varios cultivares de cacao (Theobroma cacao L.). Revista ICA, 17, 93-99.

[31] Pinto, L.R.M., Yamada, M.M. and Ahnert, D. (1998) Recomendações para determinação da incompatibilidade sexual do cacaueiro. Boletim Técnico, CEPLAC/CEPEC, Ilhéus.

[32] Leal, A.M.A. (2005) Caracterización de árboles superiores de cacao (Theobroma cacao L.) seleccionados por el programa de mejoramiento genético del CATIE. Dissertação (Mestrado em Produção Vegetal), Centro Agronômico Tropical de Investigación y Enseñanza, Costa Rica.

[33] Castillo, J. (2005) Informe de Viaje a Brasil. 22 de Octubre al 5 de Noviembre 2004. Centro de Estudios de cacao Almirante. Comissao Executiva do Plano da Lavoura Cacaueira (CEPLAC). CATIE (Centro Agronómico Tropical de Investigación y Enseñanza) (entrevista), Turrialba.

[34] Lopes, U.V., Monteiro, W.R., Pires, J.L., Clement, D., Yamada, M.M. and Gramacho, K.P. (2011) Cacao Breeding in Bahia, Brazil: Strategies and Results. Crop Breed and Applied Biotechnology, 11, 73-81. https://doi.org/10.1590/S1984-70332011000500011

[35] Silva, D.V., Araújo, I.S., Branco, S.M.J., Aguilar-Vildoso, C.I., Lopes, U.V., Marelli, J.P., Motamayor, J.C., Royaert, S., Rebouças, R.C. and Corrêa, R.X. (2014) Analysis of Resistance to Witches' Broom Disease (Moniliophthora perniciosa) in Flower Cushions of Theobroma cacao in a Segregating Population. Plant Pathology, 63, 1264-1271. https://doi.org/10.1111/ppa.12204

[36] Marita, J.M., Nienhuis, J., Pires, J.L. and Aitken, W.M. (2001) Analysis of Genetic Diversity in Theobroma cacao with Emphasis on Witches' Broom Disease Resistance. Crop Science, 41, 1305-1316. https://doi.org/10.2135/cropsci2001.4141305x

[37] Silva, S.D.V.M., Paim, M.C. and Castro, W.M. (2004) Cacau "Jaca" Resistente a Ceratocystis fimbriata na Região Cacaueira da Bahia, Brasil. Fitopatologia Brasileira, 
29, 538-540. https://doi.org/10.1590/S0100-41582004000500011

[38] Boza, E.J., Motamayor, J.C., Amores, F.M., Cedeño-Amador, S., Tondo, C.L., Livingstone III, D.S., Schnell, R.J. and Gutiérrez, A.O. (2014) Genetic Characterization of the Cacao Cultivar CCN 51: Its Impact and Significance on Global Cacao Improvement and Production. Journal of the American Society for Horticultural Science, 139, 219-229.

[39] Silva, S.D.V.M., Mandarino, E.P., Damaceno, V.O. and Santos Filho, L.P. (2007) Reação de genótipos de cacaueiros a isolados de Ceratocystis cacaofunesta. Fitopatologia Brasileira, 32, 504-506.

https://doi.org/10.1590/S0100-41582007000600009 